\title{
A Study on Mobile Banking Services with Special Reference to Ponmalai Area at Tricky
}

\author{
*Mrs. R. Buvaneswari, **Ms. B. Bharathi, ***Dr. R. Prakash Babu, \\ $* * * *$ Ms. Mahalakshmi Venkatesh, *****Mr. R. Vinoth Babu \\ *\&** Assistant Professor, Centre for Research, Department of Commerce, Srimad Andavan arts \& Science \\ College, No.7 Nelson Road, T.V.Kovil, Trichy-05. *** Associate Professor, Sri A.V.V.M Pushpam College, \\ Poondi, Thanjavur. \\ ****Asst. Teacher, SIES College of Arts, Science \& Commerce, Mumbai. \\ ****M.Com Student, Centre for Research, Department of Commerce, Srimad Andavan arts \& Science College, \\ No.7 Nelson Road, T.V.Kovil, Trichy - 05.
}

\begin{abstract}
Mobile banking is defined as the "type of execution of financial services in the course of whichwithin an electronic procedure - the customer uses mobile communication techniques in conjunction with mobile devices". Moreover, it is defined as "a channel whereby the customer interacts with a bank via a mobile device, such as a mobile phone or personal digital assistant" Today, mobile banking services enable consumers [e.g. to check the balance and transactions of their accounts, pay invoices and transfer funds between accounts, monitor the use of credit cards, check when invoices fall due, make buy and sell orders for the stock exchange and receive portfolio and price information]. It's always-on functionality and the option to bank virtually any time and anywhere characterise mobile banking services. However, mobile banking has not yet completely convinced bank customers of its usefulness and added value that it offers and its use is yet in an initial stage. Most of the users are highly satisfied with the recent developments in the banking services. There seems to be resistance to adopt these innovative banking services. Now a day's customers expect more facilities. So the banks have to update the mobile banking facilities which would satisfy the customers.
\end{abstract}

\section{Introduction}

The advent of the internet has enabled new ways to conduct banking business, resulting in the creation of new institutions, such as online banks, online brokers and wealth managers. Such institutions still account for a tiny percentage of the industry. Over the last few years, the mobile and wireless market has been one of the fastest growing markets in the world and it is still growing at a rapid pace. According to the GSM association and Ovam, the number of mobile subscribers exceeded 2 billion in September 2005, and now [exceeds 2.5 billion (of which more than 2 billion are GSM). With mobile technology, banks can offer services to their customers such as doing funds transfer while travelling, receiving online updates of stock price or even performing stock trading while being stuck in traffic. Smart phones and3G connectivity provide some capabilities that older text message-only phones do not.

According to a study by financial consultancy Client, $35 \%$ of online banking households will be using mobile banking by 2010 , up from less than $1 \%$ today. Upwards of $70 \%$ of bank center call volume is projected to come from mobile phones. Mobile banking will eventually allow users to make payments at the physical point of sale. "Mobile contactless payments" will make up 10\% of the contactless market by 2010 . Another study from 2010 by Berg Insight forecasts that the number of mobile banking users in the US will grow from 12 million in 2009 to 86 million in 2015. The same study also predicts that the European market will grow from 7 million mobile banking users in 2009 to 115 million users in 2015.

Many believe that mobile users have just started to fully utilize the data capabilities in their mobile phones. In Asian countries like India, China, Bangladesh, Indonesia and Philippines, where mobile infrastructure is comparatively better than the fixed-line infrastructure, and in European countries, where mobile phone penetration is very high (at least $80 \%$ of consumers use a mobile phone), mobile banking is likely to appeal even more. Technology can be defines as knowledge of methods to perform certain tasks efficiently and solve problems pertaining to products and services. Information technology has brought about revolutionary changes in the world and the business environments in most of the sectors have became technology dependent. Since the banking sector has been subjected to tremendous changes because of the new technology.

E-banking may be viewed as "delivery of banks services to a customer at his office or home by using electronic technology "E-banking in a nut shell, refer to use of technology for serving the customers.

It enables the customer to access banking services electronically for paying bills, transferring of funds and for obtaining information and advices. It also refers to the transactions carried at through phones, personal computers and the internet. 
The reserve bank of India and the public sector banks have realized the importance of technology to service and thrive with private and foreign banks Technology has made banking truly international and efficient Banks have introduced innovative products such as, e-banking and e-payments. The growth in banking technology and automation of banking processes has enabled the banks to expand their reach and low cost transactions with improved customer services. Customers are now demanding value added services and hence, banks have to speed up their IT implementation.

Technically specially most of these services can be deployed using more than one channel. Presently, Mobile Banking is being deployed using mobile applications developed on one of the following four channels.

1. IVR (Interactive Voice Response)

2. SMS (Short Messaging Service)

3. WAP (Wireless Access Protocol)

4. Standalone Mobile Application Clients

\section{Mobile Banking Services}

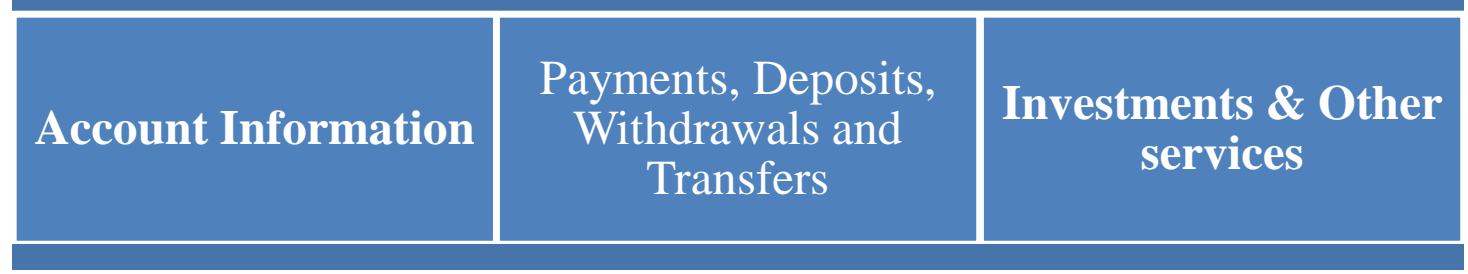

\section{Objectives Of The Study}

$\checkmark \quad$ To know the users awareness about the various services provided by banks.

$\checkmark \quad$ To know the reason for the customers going the mobile banking services.

$\checkmark \quad$ To ascertain the users level of the satisfaction with mobile banking services.

$\checkmark \quad$ To study the various factors and features that effects the decision of selecting.

$\checkmark \quad$ To know the user difficulties in using Mobile banking services.

$\checkmark \quad$ To understand the users expectation for the improvement of mobile banking services.

\section{Scope Of The Study}

The mobile banking play main role with banking services in present days. The study is conducted to find satisfaction on the customers for the mobile banking services in Ponmalai at Trichy district.

Research Design: A research design is purely and simply the frame work of plan for a study that guides the collection and analysis of the data. The project is the descriptive research design is used here.

Types Of Research: For this study descriptive research for selected. This research is the one that simply describes something such demographic of customers who use the mobile banking.

Methodology: Questionnaire is used as a data collection instrument. This questionnaire is a structured one and it consist of dichotomous questions and multiple choice questions. This questionnaire is used to collect the opinion feeling and attitudes of the respondents.

\section{Source Of Information}

Primary Data: The main source of information for this study is primary data which were collected by field work with help of questionnaire. This study is based on primary data consist of the customers. They are original in character and data are fresh and first hand information.

Secondary Data: The secondary data were already collected from the other sources like various books, news papers and magazines.

Sampling Process: Sampling is the representative of the whole population or universes. It is impossible to the entire population within the time limit given. Instead of examine the entire population called sample.

Sample Size: The sample size for this study is fifty and the method used for selection is random sampling. The samples were the selected in Ponmalai area at Trichy district.

Pre Test: The interview was pretested on 10 respondents. It was found that complete information could not be collected and few more questions were added and a few more questions were deleted.

Tools Used: Statistical tools used by the researcher to carry out the study only in percentage analysis, \& Hypothesis analysis 


\section{Limitations Of The Study}

$\checkmark$ Customers may have given biased responses.

$\checkmark$ Most of the customers were not co-operation.

$\checkmark$ The sample size fifty is very less when compared with overall existing customers. Hence generation may not be accurate.

$\checkmark$ Some customers may express high dissatisfy (even if satisfied) in order to receive more concessions.

$\checkmark$ The area of survey is conducted only in Ponmalai at Trichy district.

$\checkmark$ Hence projection of the result is the entire population of result it the entire population may give effective conclusion.

Period Of The Study: The study period from Dec 2013 to Feb 2014.

\section{Review Of Literature}

Today, we cannot think about the success of a banking system without information technology and communication. It has enlarged the role of banking sector in the economy. The financial transactions and payment can now be processed quickly and easily. The banks with the latest technology and techniques are more successful in the competitive financial market. They have been able to generate more and more business resulting in their greater profitability.

Various empirical and theoretical studies have been undertaken at the national and international level to analyze the impact of e-banking and information and communication technology (ICT) on banking sector, customers, service quality and payment system. The studies mainly focus upon e-banking impact on productivity and profitability primarily due to core banking system, electronic fund transfer, real time gross settlement system and electronic clearing services. From the customer angle the studies primarily focus upon; why customers choose e-banking products and increase in their level of satisfaction due to phone banking, mobile banking, internet banking, website services, ATMs, etc. These services have not only improved the satisfaction level of customers, but also helped in reduction of processing time and transaction time. The productivity of banks in terms of time saving and attending the customers at the branches has also improved. The review of following studies throws light upon different aspects of e-banking. To know the impact of ebanking on various aspects, studies undertaken for the review have been classified into four categories, i.e., studies related to banks, studies related to customers, studies related to service quality and studies related to technology.

It is relevant to refer briefly to the previous studies and research in the related areas of the subject to find out and to fill up the research gaps, if any. Literature on financial services can generally be found; a number of books are available on banking related aspects as merchant banking, loan syndication, securitization, profitability and productivity etc. but, few studies are undertaken on the role of technology in the banking services.

Portable ICT is defined as Cherubs situation, account transactions, payments, credit applications and banking transactions. Mobile banking is increasingly influences on consumer behavior. It will facilitate the timely delivery of customer account information, payments, deposits, withdrawals and transfer. For example, Tiwari et al (2006) are speaking about everywhere present, immediacy, local, immediate connectivity and simplified authentication method as the special interests of the customer. These benefits complement the bank in benefits such as adapt customer needs and utilize distribution channels, improved picture and create revenue. These benefits, in addition to the potential time and location - independent mobile services and the overall effort Offering quality, it is recommended that mobile banking should be valuable by users are accepted. However, it is not easy to accept it due to organizational, perceptual factors and social challenges by banks and customers.

Golden Rock Railway Workshop

Central Workshops, Golden Rock

\begin{tabular}{|l|l|}
\hline Built & 1928 \\
\hline Location & Golden Rock, Tiruchirappalli \\
\hline Industry & Railways \\
\hline Products & Rolling stock \\
\hline Employees & 6000 (Approx.) \\
\hline Architect & East India Company \\
\hline Area & 200 Acres \\
\hline Address & Golden Rock, TiruchirappalliTamil Nadu \\
\hline
\end{tabular}

The Golden Rock Railway Workshop, (officially Central Workshop, Golden Rock) is situated in Ponmalai (Golden Rock), Tiruchirappalli in the Indian state of Tamil Nadu, is one of the three mechanical railway workshops serving the southern zone of the Indian Railways. 
This repair workshop is basically a "Mechanical Workshop" which comes under the control of the Mechanical Department of the Indian Railways. The other two mechanical workshops of Southern Railway are located in Perambur, Chennai. They are "Carriage Works, Perambur" and "Loco Works, Perambur".

\section{History}

Branch shops on both sides connected by a traverse. This central workshop was set up in 1897 by South Indian Railways at Nagapattinam mainly to cater to the requirement of steam locomotive maintenance. South Indian Railways decided to shift the workshop to Trichinopoly, presently known as Tiruchchirappalli, owing to its location advantage. Consequently foundation stone was laid by Mrs. R.P. MUNRO on 20.10.1926. It was shifted to Tiruchchirappalli in 1928 because of its strategic location. The Central Workshop, Golden Rock is functioning at Tiruchchirappalli since then. The total area of this workshop is around 200 acres $\left(0.81 \mathrm{~km}^{2}\right)$, out of which 26 acres $\left(110,000 \mathrm{~m}^{2}\right)$ is covered under roof. At present 6,091 employees are working in this workshop. This workshop is primarily engaged in the activities of DSL Loco POH, heritage steam locomotive $\mathrm{POH}$, coaching stock maintenance and wagon manufacturing and other sundry activities. This workshop does have a long traverser way around 600 meters long and 80 feet $(24 \mathrm{~m})$ wide. This workshop was involved in repairing of Royal Air Force's air planes during World War II. This workshop when built had stateof-the-art facilities rarely seen in those days. It had its own powerhouse which generated electricity for the workshop and the colony. In fact, Railway colony, Golden Rock was one of the first places to be lit by electrical lights in Tiruchirappalli city those days.

Table No.- 1

Customer's Satisfaction Through Mobile Banking Service

\begin{tabular}{|c|c|c|c|}
\hline SL.NO & $\begin{array}{l}\text { CUSTOMER SATISFACTION THROUGH MOBILE } \\
\text { BANKING SERVICES }\end{array}$ & $\begin{array}{l}\text { No. of respondents } \\
(n=100)\end{array}$ & $\begin{array}{l}\text { Percentage } \\
(\mathbf{n}=\mathbf{1 0 0})\end{array}$ \\
\hline 1 & Yes & 72 & 72.0 \\
\hline 2 & No & 28 & 28.0 \\
\hline & Total & 100 & 100 \\
\hline
\end{tabular}

\section{Source: Primary data}

From the above table tells that $72 \%$ of the customers are satisfied and $28 \%$ of the customers are not satisfied the usage of mobile banking services. It indicates majority of customers are satisfied the mobile banking services.

Table No: 2

Bank Offer Any Of The Following Mobile Banking Services

\begin{tabular}{|c|l|c|c|}
\hline \multirow{2}{*}{ SL.NO } & \multicolumn{1}{|c|}{$\begin{array}{c}\text { BANK OFFER ANY OF THE FOLLOWING MOBILE } \\
\text { BANKING SERVICES }\end{array}$} & $\begin{array}{c}\text { No. of respondents } \\
(\mathbf{n = 1 0 0})\end{array}$ & $\begin{array}{c}\text { Percentage } \\
(\mathbf{n}=\mathbf{1 0 0})\end{array}$ \\
\hline $\mathbf{1}$ & \multicolumn{1}{|c|}{ Minimum balance alerts } & 40 & 40.0 \\
\hline $\mathbf{2}$ & Bill payment & 37 & 37.0 \\
\hline $\mathbf{3}$ & Financial services like share trading & 16 & 16.0 \\
\hline $\mathbf{4}$ & Other (Specified) & $\mathbf{1}$ & 7.0 \\
\hline & Total & $\mathbf{1 0 0}$ & $\mathbf{1 0 0}$ \\
\hline
\end{tabular}

Source: Primary data

From the above table shows that $40 \%$ of them using the minimum balance alerts, $37 \%$ of them using bill payment, $16 \%$ of them using financial services and remaining $7 \%$ of them using other work.

Table No: 3

Opinion Of Advantages Of Mobile Banking

\begin{tabular}{|c|l|c|c|}
\hline \multirow{2}{*}{ SL.NO } & \multicolumn{1}{|c|}{ ADVANTAGES } & $\begin{array}{c}\text { No. of respondents } \\
(\mathbf{n = 1 0 0})\end{array}$ & $\begin{array}{c}\text { Percentage } \\
(\mathbf{n = 1 0 0})\end{array}$ \\
\hline $\mathbf{1}$ & $\begin{array}{l}\text { Ubiquitous "anytime anywhere" Conducting of bank } \\
\text { business }\end{array}$ & 17 & 17.0 \\
\hline $\mathbf{2}$ & Fast reaction to market developments & 57 & 57.0 \\
\hline $\mathbf{3}$ & Overview over bank accounts & 14 & 14.0 \\
\hline $\mathbf{4}$ & Nothing & 8 & 8.0 \\
\hline $\mathbf{5}$ & Others & 4 & 4.0 \\
\hline & Total & $\mathbf{1 0 0}$ & $\mathbf{1 0 0}$ \\
\hline
\end{tabular}

Source: Primary data 
From the above table tells that $57 \%$ of them given the opinion for Fast reaction to market developments, $17 \%$ of them given Ubiquitous "anytime anywhere" Conducting of bank business, $14 \%$ of them given Overview over bank accounts, $8 \%$ of them given Nothing, \& $5 \%$ of them given Others.

Table no: 4

Opinion Of Disadvantages Of Mobile Banking

\begin{tabular}{|c|l|c|c|}
\hline SL.NO & \multicolumn{1}{|c|}{ DIS ADVANTAGES } & \multicolumn{1}{|c|}{$\begin{array}{c}\text { No. of respondents } \\
(\mathbf{n = 1 0 0})\end{array}$} & $\begin{array}{c}\text { Percentage } \\
(\mathbf{n}=\mathbf{1 0 0})\end{array}$ \\
\hline $\mathbf{1}$ & Security concerns risk & 25 & 25.0 \\
\hline $\mathbf{2}$ & $\begin{array}{l}\text { Complicated (un comfortable usage of mobile } \\
\text { devices }\end{array}$ & 34 & 34.0 \\
\hline $\mathbf{3}$ & Too expensive & 14 & 14.0 \\
\hline $\mathbf{4}$ & Nothing & 27 & 27.0 \\
\hline & Total & $\mathbf{1 0 0}$ & $\mathbf{1 0 0}$ \\
\hline
\end{tabular}

Source: Primary data

From the above table tells that $34 \%$ of them given the opinion for uncomfortable usage of mobile devices, $27 \%$ of them given no disadvantage to use mobile banking, $25 \%$ of them given security concerns risk and remaining $14 \%$ of them given too expensive to use mobile banking device.

Table No.5

Opinion Makes Mobile Banking More Attractive

\begin{tabular}{|c|l|c|c|}
\hline \multirow{2}{*}{ SL.NO } & \multicolumn{1}{|c|}{ OPINION MAKES MOBILE BANKING MORE } \\
ATTRACTIVE & \multicolumn{1}{|c|}{$\begin{array}{c}\text { No. of respondents } \\
(\mathbf{n}=\mathbf{1 0 0})\end{array}$} & $\begin{array}{c}\text { Percentage } \\
(\mathbf{n}=\mathbf{1 0 0})\end{array}$ \\
\hline $\mathbf{1}$ & Mobile devices with bigger display & 33 & 33.0 \\
\hline $\mathbf{2}$ & Better input devices & 41 & 41.0 \\
\hline $\mathbf{3}$ & Others & 26 & 26.0 \\
\hline
\end{tabular}

Source: Primary data

From the above table indicates that $41 \%$ of them given the opinion make mobile banking more attractive better input devices, $33 \%$ of them given the opinion mobile devices with bigger display and remaining $26 \%$ of them other reasons.

\section{Research hypothesis}

There is a significant association between age of the respondents and their opinion about mobile banking services

Null hypothesis: There is no significant association between age of the respondents and their opinion about mobile banking services

\begin{tabular}{|c|c|c|c|c|}
\hline \multirow{2}{*}{ Age } & \multicolumn{3}{|c|}{ Mobile banking services } & \multirow{2}{*}{ Statistical inference } \\
\cline { 2 - 4 } & $\begin{array}{c}\text { Yes } \\
(\mathbf{n = 7 3 )}\end{array}$ & $\begin{array}{c}\text { No } \\
(\mathbf{n = 2 7})\end{array}$ & $\begin{array}{c}\text { Total } \\
(\mathbf{n = 1 0 0})\end{array}$ & \\
\hline Below 20yrs & $5(6.8 \%)$ & $2(7.4 \%)$ & $7(7 \%)$ & \multirow{2}{*}{$\mathrm{X}^{2}=3.736 \mathrm{Df}=3$} \\
\hline 20 to 30yrs & $50(68.5 \%)$ & $23(85.2 \%)$ & $73(73 \%)$ & $\begin{array}{c}.291>0.05 \\
\text { Not Significant }\end{array}$ \\
\hline 30 to 40yrs & $11(15.1 \%)$ & $1(3.7 \%)$ & $12(12 \%)$ & \multirow{2}{*}{} \\
\hline Above 40yrs & $7(9.6 \%)$ & $1(3.7 \%)$ & $8(8 \%)$ & \\
\hline
\end{tabular}

The above table reveals that there is no significant association between age of the respondents and their opinion about mobile banking services. Hence, the calculated value greater than table value $(\mathrm{p}>0.05)$.

\section{Findings}

The above table reveals that there is no significant association between age of the respondents and their opinion about mobile banking services. Hence, the calculated value greater than table value $(p>0.05)$. So the research hypothesis is rejected and the null hypothesis is accepted.

\section{Association Between Gender Of The Respondents And Their Opinion About Mobile Banking Services Research hypothesis}

There is a significant association between gender of the respondents and their opinion about mobile banking services

\section{Null hypothesis}


There is no significant association between gender of the respondents and their opinion about mobile banking services

\begin{tabular}{|c|c|c|c|c|}
\hline \multirow[b]{2}{*}{ Gender } & \multicolumn{3}{|c|}{ Mobile banking services } & \multirow[b]{2}{*}{ Statistical inference } \\
\hline & $\begin{array}{c}\text { Yes } \\
(n=73)\end{array}$ & $\begin{array}{c}\text { No } \\
(\mathrm{n}=27)\end{array}$ & $\begin{array}{c}\text { Total } \\
(\mathbf{n}=\mathbf{1 0 0})\end{array}$ & \\
\hline Male & $45(61.6 \%)$ & $19(70.4 \%)$ & $64(64 \%)$ & $\mathrm{X}^{2}=.651 \mathrm{Df}=1$ \\
\hline Female & $28(38.4 \%)$ & $8(29.6 \%)$ & $36(36 \%)$ & $\begin{array}{c}.420>0.05 \\
\text { Not Significant }\end{array}$ \\
\hline
\end{tabular}

The above table reveals that there is no significant association between gender of the respondents and their opinion about mobile banking services. Hence, the calculated value greater than table value $(p>0.05)$.

Findings: The above table reveals that there is no significant association between gender of the respondents and their opinion about mobile banking services. Hence, the calculated value greater than table value $(p>0.05)$. So the research hypothesis is rejected and the null hypothesis is accepted.

\section{Association Between Marital Status Of The Respondents And Their Opinion About Mobile Banking Services Research hypothesis}

There is a significant association between marital status of the respondents and their opinion about mobile banking services

Null hypothesis

There is no significant association between marital status of the respondents and their opinion about mobile banking services

\begin{tabular}{|l|c|c|c|c|}
\hline \multirow{2}{*}{ Marital status } & \multicolumn{3}{|c|}{ Mobile banking services } & \multirow{2}{*}{ Statistical inference } \\
\cline { 2 - 4 } & $\begin{array}{c}\text { Yes } \\
(\mathbf{n = 7 3})\end{array}$ & $\begin{array}{c}\text { No } \\
(\mathbf{n = 2 7})\end{array}$ & $\begin{array}{c}\text { Total } \\
(\mathbf{n = 1 0 0})\end{array}$ & \\
\hline Married & $20(27.4 \%)$ & $2(7.4 \%)$ & $22(22 \%)$ & $\mathrm{X}^{2}=4.590 \mathrm{Df}=1$ \\
Unmarried & $53(72.6 \%)$ & $25(92.6 \%)$ & $78(78 \%)$ & $\begin{array}{c}.032<0.05 \\
\text { Significant }\end{array}$ \\
\hline
\end{tabular}

The above table reveals that there is a significant association between marital status of the respondents and their opinion about mobile banking services. Hence, the calculated value less than table value $(\mathrm{p}<0.05)$.

\section{Findings}

The above table reveals that there is a significant association between marital status of the respondents and their opinion about mobile banking services. Hence, the calculated value less than table value $(p<0.05)$. So the research hypothesis is accepted and the null hypothesis is rejected.

\section{Association Between Educational Qualification Of The Respondents And Their Opinion About Mobile Banking Services Research hypothesis}

There is a significant association between educational qualification of the respondents and their opinion about mobile banking services

\section{Null hypothesis}

There is no significant association between educational qualification of the respondents and their opinion about mobile banking services

\begin{tabular}{|c|c|c|c|c|}
\hline \multirow[b]{2}{*}{ Educational qualification } & \multicolumn{3}{|c|}{ Mobile banking services } & \multirow[b]{2}{*}{ Statistical inference } \\
\hline & $\begin{array}{c}\text { Yes } \\
(n=73)\end{array}$ & $\begin{array}{c}\text { No } \\
(n=27)\end{array}$ & $\begin{array}{c}\text { Total } \\
(\mathbf{n}=100)\end{array}$ & \\
\hline School education & $12(16.4 \%)$ & $5(18.5 \%)$ & $17(17 \%)$ & \multirow{4}{*}{$\begin{array}{c}\mathrm{X}^{2}=2.830 \mathrm{Df}=3 \\
.419>0.05 \\
\text { Not Significant }\end{array}$} \\
\hline Under Graduate & $21(28.8 \%)$ & $8(29.6 \%)$ & $29(29 \%)$ & \\
\hline Post Graduate & $33(45.2 \%)$ & $14(51.9 \%)$ & $47(47 \%)$ & \\
\hline Professionals & $7(9.6 \%)$ & 0 & $7(7 \%)$ & \\
\hline
\end{tabular}

The above table reveals that there is no significant association between educational qualification of the respondents and their opinion about mobile banking services. Hence, the calculated value greater than table value $(\mathrm{p}>0.05)$. 
Findings

The above table reveals that there is no significant association between educational qualification of the respondents and their opinion about mobile banking services. Hence, the calculated value greater than table value ( $p>0.05)$. So the research hypothesis is rejected and the null hypothesis is accepted.

\section{Association Between Occupation Of The Respondents And Their Opinion About Mobile Banking Services \\ Research hypothesis}

There is a significant association between occupation of the respondents and their opinion about mobile banking services

\section{Null hypothesis}

There is no significant association between occupation of the respondents and their opinion about mobile banking services

\begin{tabular}{|l|c|c|c|c|}
\hline \multirow{2}{*}{ Occupation } & \multicolumn{3}{|c|}{ Mobile banking services } & \multirow{2}{*}{ Statistical inference } \\
\cline { 2 - 4 } & $\begin{array}{c}\text { Yes } \\
(\mathbf{n = 7 3})\end{array}$ & $\begin{array}{c}\text { No } \\
(\mathbf{n = 2 7})\end{array}$ & $\begin{array}{c}\text { Total } \\
(\mathbf{n = 1 0 0})\end{array}$ & \\
\hline Business man & $10(13.7 \%)$ & 0 & $10(10 \%)$ & \multirow{2}{*}{$\mathrm{X}^{2}=8.909 \mathrm{Df}=4$} \\
\hline Government Employees & $14(19.2 \%)$ & $2(7.4 \%)$ & $16(16 \%)$ & $.063>0.05$ \\
\hline Professionals & $10(13.7 \%)$ & $6(22.2 \%)$ & $16(16 \%)$ & \multirow{2}{*}{$\begin{array}{c}.06 \\
\text { Pot Significant }\end{array}$} \\
\hline Private Employees & $16(21.9 \%)$ & $11(40.7 \%)$ & $27(27 \%)$ & \\
\hline Others & $23(31.5 \%)$ & $8(29.6 \%)$ & $31(31 \%)$ & \\
\hline
\end{tabular}

The above table reveals that there is no significant association between occupation of the respondents and their opinion about mobile banking services. Hence, the calculated value greater than table value $(p>0.05)$. Findings: The above table reveals that there is no significant association between occupation of the respondents and their opinion about mobile banking services. Hence, the calculated value greater than table value $(p>0.05)$. So the research hypothesis is rejected and the null hypothesis is accepted.

\section{Association Between Monthly Income Of The Respondents And Their Opinion About Mobile Banking Services Research hypothesis}

There is a significant association between monthly income of the respondents and their opinion about mobile banking services

\section{Null hypothesis}

There is no significant association between monthly income of the respondents and their opinion about mobile banking services

\begin{tabular}{|c|c|c|c|c|}
\hline \multirow[b]{2}{*}{ Monthly income } & \multicolumn{3}{|c|}{ Mobile banking services } & \multirow[b]{2}{*}{ Statistical inference } \\
\hline & $\begin{array}{c}\text { Yes } \\
(n=73)\end{array}$ & $\begin{array}{c}\text { No } \\
(n=27)\end{array}$ & $\begin{array}{c}\text { Total } \\
(n=100)\end{array}$ & \\
\hline Below Rs.10000 & $33(45.2 \%)$ & $17(63 \%)$ & $50(50 \%)$ & \multirow{4}{*}{$\begin{array}{c}\mathrm{X}^{2}=4.208 \mathrm{Df}=3 \\
.240>0.05 \\
\text { Not Significant }\end{array}$} \\
\hline Rs. 10000 to 20000 & $25(34.2 \%)$ & $8(29.6 \%)$ & $33(33 \%)$ & \\
\hline Rs. 20000 to 30000 & $8(11 \%)$ & $2(7.4 \%)$ & $10(10 \%)$ & \\
\hline Above Rs.30000 & $7(9.6 \%)$ & 0 & $7(7 \%)$ & \\
\hline
\end{tabular}

The above table reveals that there is no significant association between monthly income of the respondents and their opinion about mobile banking services. Hence, the calculated value greater than table value $(\mathrm{p}>0.05)$.

Statistical Test: Chi-square test was used the above table

Findings: The above table reveals that there is no significant association between monthly income of the respondents and their opinion about mobile banking services. Hence, the calculated value greater than table value $(\mathrm{p}>0.05)$. So the research hypothesis is rejected and the null hypothesis is accepted.

\section{Oneway Anova Difference Between Monthly Income Of The Respondents And Their Opinion About Satisfied Through Mobile Banking Services Research hypothesis}

There is a significant difference between monthly income of the respondents and their opinion about satisfied through mobile banking services 
Null hypothesis

There is no significant difference between monthly income of the respondents and their opinion about satisfied through mobile banking services

\begin{tabular}{|c|c|c|c|c|c|c|}
\hline Satisfied through mobile banking services & Mean & S.D & SS & Df & MS & Statistical inference \\
\hline Between Groups & & & .979 & 3 & .326 & \multirow{6}{*}{$\begin{array}{c}\mathrm{F}=1.634 \\
.187>0.05 \\
\text { Not Significant }\end{array}$} \\
\hline Below Rs.10000 $(n=50)$ & 1.36 & .485 & & & & \\
\hline Rs.10000 to $20000(n=33)$ & 1.24 & .435 & & & & \\
\hline Rs.20000 to $30000(n=10)$ & 1.20 & .422 & & & & \\
\hline Above Rs.30000(n=7) & 1.00 & .000 & & & & \\
\hline Within Groups & & & 19.181 & 96 & .200 & \\
\hline
\end{tabular}

The above table reveals that there is no significant difference between monthly income of the respondents and their opinion about satisfied through mobile banking services. Hence, the calculated value greater than table value $(\mathrm{p}>0.05)$.

\section{Statistical test}

One-way ANOVA ' $\mathrm{f}$ ' test was used the above table

Findings: The above table reveals that there is no significant difference between monthly income of the respondents and their opinion about satisfied through mobile banking services. Hence, the calculated value greater than table value $(\mathrm{p}>0.05)$. So the research hypothesis is rejected and the null hypothesis is accepted.

\section{Oneway Anova Difference Between Type Of Account Of The Respondents And Their Opinion About Satisfied Through Mobile Banking Services \\ Research hypothesis}

There is a significant difference between type of account of the respondents and their opinion about satisfied through mobile banking services

\section{Null hypothesis}

There is no significant difference between type of account of the respondents and their opinion about satisfied through mobile banking services

\begin{tabular}{|l|c|c|c|c|c|c|}
\hline Satisfied through mobile banking services & Mean & S.D & SS & Df & MS & Statistical inference \\
\hline Between Groups & & & 1.015 & 2 & .508 & \multirow{2}{*}{$\mathrm{F}=2.571$} \\
\hline Current $(\mathrm{n}=22)$ & 1.14 & .351 & & & & $.082>0.05$ \\
\cline { 1 - 5 } Savings $(\mathrm{n}=74)$ & 1.34 & .476 & & & & Not Significant \\
\hline Both $(\mathrm{n}=4)$ & 1.00 & .000 & & & & \\
\hline Within Groups & & & 19.145 & 97 & .197 & \\
\hline
\end{tabular}

The above table reveals that there is no significant difference between type of account of the respondents and their opinion about satisfied through mobile banking services. Hence, the calculated value greater than table value $(\mathrm{p}>0.05)$.

Statistical test: One way ANOVA ' $F$ ' test was used the above table

Findings: The above table reveals that there is no significant difference between type of account of the respondents and their opinion about satisfied through mobile banking services. Hence, the calculated value greater than table value $(\mathrm{p}>0.05)$. So the research hypothesis is rejected and the null hypothesis is accepted

\section{Findings}

* It indicates majority (74\%) of the customers are maintaining the savings accounts.

* It indicates majority $(73 \%)$ of them having mobile banking services.

* It indicates majority (40\%) of the customers are use this mobile banking service in below one year.

* It indicates majority (83\%) of customers are having convenient accessibility of their mobile phone.

* It indicates majority $(72 \%)$ of the customers are satisfied.

* It indicates majority (53\%) of them feel about the security for somewhat secure

* It indicates majority (53\%) of them tells that a bank and a mobile operator together.

* It indicates majority (32\%) of them hearing only for mass media.

* It indicates majority (28\%) of them given the rank for excellent service relating to SMS for new schemes.

* It indicates majority ( $57 \%$ of them given the opinion for Fast reaction to market developments.

* It indicates majority (34\%) of them given the opinion for uncomfortable usage of mobile devices.

* It indicates majority ( $41 \%$ ) of them given the opinion make mobile banking more attractive better input devices. 
* Research hypothesis is rejected and the null hypothesis is accepted for the following tables tested in Chi-square.

1. Association between age of the respondents and their opinion about mobile banking services

2. Association between Gender of the respondents and their opinion about mobile banking services

3. Association between Marital Status of the respondents and their opinion about mobile banking services

4. Association between Educational qualification of the respondents and their opinion about mobile banking services

5. Association between Occupation of the respondents and their opinion about mobile banking services

6. Association between Monthly income of the respondents and their opinion about mobile banking services

* One way analysis findings, the research hypothesis is rejected and the null hypothesis is accepted for the following tables test.

1. One way ANOVAs difference between Monthly income of the respondents and their opinion about mobile banking services

2. One way ANOVAs difference between Type of account of the respondents and their opinion about mobile banking services

\section{Suggestions}

* The bankers should establish a strong network system to provide interrupted mobile banking services.

* The public sector banks should educate their account holders to use and avail the benefits of mobile banking services.

* The bankers should maintain a special section for mobile banking services to meet their customer needs and to serve them better.

* The bankers should maintain a special section for mobile banking services to meet their customer needs and to serve them.

* The banker should improve belief level of account holders on the security system of mobile banking services.

* The bankers should explain all the schemes to their customers.

\section{Conclusion}

Most of the users are highly satisfied with the recent developments in the banking services. If the necessary efforts are taken to maintain the services and to attract the new users by various promotional activities, the need for mobile banking will certainly increase in future and there will be the possibility for new competitions to enter into the banking market. Now a day's customers expect more facilities. So the banks have to update the mobile banking facilities which would satisfy the customers.

\section{Bibliography}

[1]. Farnood,H.(2008).Sultanate.Soheila, "mobile banking", Journal of Information TechnologyEra,No. 38

[2]. MARKETING MANAGEMENT : Kothari, Mehta, sharma

[3]. Publisher : Ramesh Book Depot.

[4]. Jaipur - New Delhi.

[5]. MARKETING MANAGEMENT : Philip Kolter

[6]. Publisher : Prentice - Half of India Pvt. Ltd.

[7]. New Delhi

[8]. MARKETING MANAGEMENT : Rajan Saxena

[9]. Publisher : Tata Mc Graw-Hill Publishing

[10]. company Ltd. New Delhi.

[11]. Consumer behavior : P.C. Jain Monika Bhatt S.Chand

[12]. Publications

[13]. Marketing Management : Rajan Nair 